\title{
Justyna Sadowska
}

Uniwersytet Łódzki

justynasadowska@op.pl

\section{Orzeczenie sądu opiekuńczego w przedmiocie wyrażenia zgody na pobranie od małoletniego szpiku lub komórek krwiotwórczych krwi obwodowej}

Ruling of the Guardianship Court on the Subject of Consent to Collect Bone Marrow or Peripheral Blood Haematopoietic Cells from the Juvenile

\section{STRESZCZENIE}

Artykuł dotyczy problematyki orzeczenia wydanego w jednym z postępowań cywilnych uregulowanych w ustawie z dnia 1 lipca 2005 r. o pobieraniu, przechowywaniu i przeszczepianiu komórek, tkanek i narządów, a mianowicie w postępowaniu w przedmiocie wyrażenia zgody przez sąd opiekuńczy na pobranie szpiku lub komórek krwiotwórczych krwi obwodowej od małoletniego. W pierwszej kolejności zostały omówione zagadnienia dotyczące treści orzeczenia, czasu i miejsca orzekania, postaci orzeczenia oraz jego charakteru prawnego. Dalsze rozważania dotyczą cech i skutków orzeczenia, w tym: prawomocności, niezmienności, powagi rzeczy osądzonej, skuteczności i wykonalności. Autorka porusza ponadto istotną problematykę uzasadnienia postanowienia i doręczenia tego uzasadnienia.

Słowa kluczowe: orzeczenie sądu opiekuńczego; postępowanie w sprawie pobrania od małoletniego szpiku albo komórek krwi; zgoda sądu opiekuńczego

\section{WSTĘP}

W przepisach art. 12 ust. 3-6 ustawy z dnia 1 lipca 2005 r. o pobieraniu, prze-

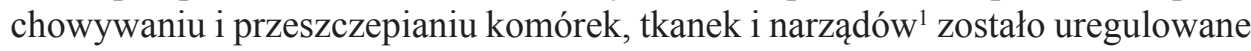
postępowanie w przedmiocie wyrażenia zgody przez sąd opiekuńczy na pobranie

\footnotetext{
1 T.j. Dz.U. z 2017 r., poz. 1000, dalej jako: u.tr.
} 
szpiku lub komórek krwiotwórczych krwi obwodowej od małoletniego. Postępowanie to toczy się przed sądem opiekuńczym w trybie nieprocesowym.

Zgodnie z art. 12 ust. 3 u.tr. pobranie szpiku lub komórek krwiotwórczych krwi obwodowej od małoletniego, który nie posiada pełnej zdolności do czynności prawnych, może być dokonane za zgodą przedstawiciela ustawowego po uzyskaniu zgody sądu opiekuńczego właściwego ze względu na miejsce zamieszkania kandydata na dawcę. W przypadku, gdy dawcą szpiku jest małoletni powyżej lat 13, wymagana jest także jego zgoda. Przepis art. 12 ust. 4 u.tr. stanowi, że sąd orzeka - na wniosek przedstawicieli ustawowych - kandydata na dawcę po wysłuchaniu małoletniego i zasięgnięciu opinii biegłego psychologa, a w przypadku małoletniego powyżej lat 16 - również na jego wniosek. Do wniosku należy dołączyć orzeczenie lekarskie stwierdzające, że pobranie szpiku nie spowoduje dającego się przewidzieć upośledzenia organizmu dawcy. Rozpoznanie wniosku następuje w terminie 7 dni (art. 12 ust. 5 u.tr.).

\section{TREŚĆ ORZECZENIA}

Sąd opiekuńczy może wydać w analizowanym postępowaniu postanowienie merytoryczne pozytywne (tj. uwzględniające wniosek) bądź negatywne (tj. oddalające wniosek). Sąd wyraża zgodę na pobranie szpiku lub komórek krwiotwórczych krwi obwodowej od małoletniego lub odmawia jej wyrażenia po rozważeniu wszelkich okoliczności konkretnej sprawy.

Jeżeli sąd opiekuńczy stwierdzi, że zostały spełnione przesłanki, od których istnienia zależy dopuszczalność dokonania przeszczepu od małoletniego dawcy², wówczas wyda orzeczenie uwzględniające wniosek. Sąd wyda orzeczenie pozytywne, jeżeli:

- zachodzi bezpośrednie niebezpieczeństwo utraty życia rodzeństwa małoletniego dawcy, a niebezpieczeństwa takiego nie można uniknąć w inny sposób niż przez dokonanie przeszczepu szpiku lub komórek krwiotwórczych krwi obwodowej (art. 12 ust. 2 u.tr.),

- dokonanie przeszczepu nie spowoduje dającego się przewidzieć upośledzenia sprawności organizmu małoletniego dawcy (art. 12 ust. 2 u.tr.),

2 Por. E.M. Guzik-Makaruk, Transplantacja organów, tkanek i komórek w ujęciu prawnym $i$ kryminologicznym, Białystok 2008, s. 300; K. Mularski, Problematyka przeszczepu od małoletniego żywego dawcy, „Państwo i Prawo” 2013, z. 7, s. 58; J. Haberko, [w:] J. Haberko, I. Uhrynowska-Tyszkiewicz, Ustawa o pobieraniu, przechowywaniu i przeszczepianiu komórek, tkanek $i$ narzqdów. Komentarz, Warszawa 2014, s. 134. 
- przedstawiciel ustawowy małoletniego dawcy wyrazi zgodę na pobranie szpiku lub komórek krwiotwórczych krwi obwodowej (art. 12 ust. 3 zd. 1 u.tr.),

- małoletni dawca szpiku w wieku powyżej lat 13 wyrazi zgodę na pobranie (art. 12 ust. 3 zd. 2 u.tr.),

- po wysłuchaniu małoletniego ${ }^{3}$ i zasięgnięciu opinii biegłego psychologa sąd nabierze przekonania o zasadności pobrania szpiku lub komórek krwiotwórczych krwi obwodowej (art. 12 ust. 4 zd. 1 u.tr.).

Powyższe przesłanki dopuszczalności dokonania przeszczepu od małoletniego dawcy powinny być spełnione kumulatywnie. W konsekwencji w braku choćby jednej z nich sąd wyda postanowienie oddalające wniosek.

Sąd opiekuńczy w treści postanowienia merytorycznego powinien skonkretyzować dawcę, biorcę i przedmiot transplantacji. Dawcę i biorcę należy określić przez podanie imion, nazwiska, numeru PESEL, miejsca zamieszkania, danych osobowych rodziców. Sąd opiekuńczy wydaje postanowienie o następującej treści: „Sąd Rejonowy dla Łodzi-Śródmieście w Lodzi VII Wydział Rodzinny i Nieletnich wyraża zgodę na pobranie od małoletniego dawcy Jana Piotra Nowaka, syna Bożeny Nowak i Marcina Nowaka, zamieszkałego w Łodzi przy ul. Kwiatowej 3/4, nr PESEL 152206134517, szpiku z przeznaczeniem dla jego brata Dawida Sebastiana Nowaka, syna Bożeny Nowak i Marcina Nowaka, zamieszkałego w Łodzi przy ul. Kwiatowej 3/4, nr PESEL 142202192817”.

\section{CZAS I MIEJSCE ORZEKANIA}

Zasady dotyczące orzekania, obowiązujące w procesie, znajdują zastosowanie w postępowaniu nieprocesowym (art. 316-322 w zw. z art. 13 § 2 k.p.c.). W konsekwencji w postępowaniu nieprocesowym obowiązują podobne jak w procesie zasady dotyczące czasu i miejsca orzekania ${ }^{4}$. Sąd rozstrzyga sprawę w postępowaniu nieprocesowym, biorąc za podstawę stan rzeczy istniejący w chwili zamknięcia

3 Wysłuchanie dziecka w analizowanym postępowaniu ma charakter względnie obligatoryjny i o jego dokonaniu decydują walory podmiotowe dziecka. Por. J. Gudowski, [w:] Kodeks postępowania cywilnego. Komentarz, t. 4: Postępowanie rozpoznawcze. Postępowanie zabezpieczające, red. T. Ereciński, Warszawa 2016, s. 285; A. Kallaus, Udział osoby małoletniej w postępowaniu opiekuńczym, Poznań 2015, s. 107.

4 Szerzej na temat tych zasad zob. W. Siedlecki, Zasady wyrokowania w procesie cywilnym, Warszawa 1957, s. 158 i n.; idem, Zasady orzekania w postepowaniu cywilnym, „Nowe Prawo” 1965, nr 6, s. 587 i n.; idem, Zasady orzekania oraz zasady zaskarżania orzeczeń sadowych w postępowaniu cywilnym w świetle orzecznictwa Sąu Najwyższego, Warszawa 1982, s. 27 i n. 
rozprawy ${ }^{5}$ (art. $316 \S 1 \mathrm{w}$ zw. z art. $13 \S 2$ k.p.c.). Jeżeli zaś rozprawa nie była wyznaczona, sąd bierze za podstawę stan rzeczy z chwili wydania postanowienia co do istoty sprawy, a więc z chwili ogłoszenia postanowienia wydanego na posiedzeniu jawnym albo podpisania postanowienia wydanego na posiedzeniu niejawnym ${ }^{6}$.

Sąd opiekuńczy orzeka w przedmiocie wyrażenia zgody na pobranie od małoletniego szpiku lub komórek krwiotwórczych krwi obwodowej co do zasady na posiedzeniu jawnym niebędącym rozprawą. Zasadą w postępowaniu nieprocesowym jest bowiem rozpoznanie spraw na posiedzeniach jawnych niebędących rozprawą ${ }^{7}$. Przepis art. 148 § 1 k.p.c. w części stwierdzającej, że posiedzenia sądowe są jawne, stosuje się odpowiednio - na podstawie art. $13 \S 2$ k.p.c. - do postępowania nieprocesowego. W efekcie wszystkie sprawy, co do których ustawa milczy w tej kwestii, trzeba rozpoznawać na posiedzeniu jawnym.

Zgodnie z art. $514 \S 1$ k.p.c. rozprawa w postępowaniu nieprocesowym odbywa się w wypadkach wskazanych w ustawie. Przepis szczególny może wobec tego wprowadzać obligatoryjne przeprowadzenie rozprawy. W przepisach regulujących postępowanie w przedmiocie wyrażenia zgody na pobranie od małoletniego szpiku lub komórek krwi nie ma jednak przepisu szczególnego, który nakładałby na sąd obowiązek wyznaczenia rozprawy ${ }^{8}$. W analizowanym postępowaniu wyznaczenie rozprawy będzie zależało od uznania sądu.

Jak wyżej wskazano, sąd opiekuńczy orzeka w przedmiocie wyrażenia zgody na pobranie od małoletniego szpiku lub komórek krwiotwórczych krwi obwodowej co do zasady na posiedzeniu jawnym niebędącym rozprawą. W konsekwencji wydaje on postanowienie co do istoty sprawy, biorąc za podstawę stan rzeczy istniejący w chwili wydania postanowienia, czyli w chwili jego ogłoszenia. Sąd musi uwzględnić wszelkie zmiany, zaszłe już w toku postępowania, dotyczące okoliczności faktycznych i prawnych rozpoznawanej sprawy. W przeciwnym razie rozstrzygnięcie sądu nie byłoby zgodne z prawdą i mogłoby być nieaktualne w momencie jego wydania9. Jeżeli natomiast sąd orzeka na rozprawie, wówczas rozstrzyga sprawę, biorąc za podstawę stan rzeczy istniejący w chwili zamknięcia rozprawy (art. $316 \S 1 \mathrm{w}$ zw. z art. $13 \S 2$ k.p.c.). Należy przy tym zaznaczyć, że rozprawa powinna być otwarta na nowo, o ile istotne okoliczności

5 Sąd bierze pod uwagę stan rzeczy istniejący w chwili rozstrzygania, który jest identyczny z chwilą zamknięcia rozprawy, jeżeli była ona przeprowadzona. Zob. M. Rejdak, [w:] Kodeks postępowania cywilnego, t. 2: Komentarz. Art. 367-729, red. A. Marciniak, K. Piasecki, Warszawa 2016, s. 700.

6 I. Kunicki, [w:] Kodeks postępowania cywilnego, t. 1: Komentarz. Art. 1-729, red. A. Góra-Błaszczykowska, Warszawa 2016, s. 1612. Por. J. Gudowski, op. cit., s. 81.

$7 \mathrm{~W}$ postępowaniu nieprocesowym, odmiennie niż w procesie, zasadą jest rozpoznanie sprawy bez rozprawy. Zob. W. Siedlecki, Z. Świeboda, Postępowanie nieprocesowe, Warszawa 2001, s. 72.

8 Por. H. Haak, Władza rodzicielska. Komentarz, Torun 1995, s. 209.

9 Por. W. Siedlecki, Zasady orzekania w postępowaniu cywilnym, s. 597; idem, Zasady orzekania oraz zasady zaskarżania ..., s. 32. 
ujawniły się dopiero po jej zamknięciu (art. $316 \S 2 \mathrm{w}$ zw. z art. $13 \S 2$ k.p.c.) ${ }^{10}$. Skorzystanie przez sąd ze wskazanej możliwości w sprawach, w których treść orzeczenia uzależniona jest od dobra osoby, której postępowanie dotyczy, jest obligatoryjne $\mathrm{z}$ uwagi na odpowiednie stosowanie art. $316 \S 2 \mathrm{w} \mathrm{zw} . \mathrm{z}$ art. $13 \S 2$ k.p.c. $\mathrm{z}$ uwzględnieniem art. 577 k.p.c. ${ }^{11}$

\section{POSTAĆ ORZECZENIA}

Przepis art. 12 ust. 4 u.tr. nie określa postaci rozstrzygnięcia sądu opiekuńczego, ograniczając się jedynie do stwierdzenia: „sąd orzeka”. W tym zakresie zatem należy odnieść się do art. 516 k.p.c., zgodnie z którym orzeczenia sądu w postępowaniu nieprocesowym zapadają w formie postanowień, chyba że przepis szczególny stanowi inaczej. Przytoczony przepis posługuje się terminem „forma postanowienia". Należy jednak uznać, że chodzi tu o postać orzeczenia, a nie o jego formę ${ }^{12}$. Orzeczenie sądu opiekuńczego w przedmiocie wyrażenia zgody na pobranie od małoletniego szpiku lub komórek krwiotwórczych krwi obwodowej zapada wobec tego w postaci postanowienia.

Wskazane postanowienie jest postanowieniem orzekającym co do istoty sprawy $\mathrm{i}$ odpowiada $\mathrm{w}$ swej treści wyrokowi $\mathrm{w}$ procesie cywilnym ${ }^{13}$. Co istotne, $\mathrm{w}$ postępowaniu nieprocesowym należy odróżnić postanowienia co do istoty sprawy (tj. merytoryczne $)^{14} \mathrm{i}$ inne postanowienia, czyli proceduralne (tj. orzekające w kwestiach dotyczących postępowania $)^{15}$. W analizowanym postępowaniu sąd opiekuńczy wydaje postanowienie merytoryczne (tj. w przedmiocie wyrażenia zgody na pobranie od małoletniego szpiku lub komórek krwiotwórczych krwi obwodowej) oraz szereg postanowień proceduralnych (np. w przedmiocie dopuszczenia dowodu).

${ }^{10}$ K. Markiewicz, Zasady orzekania w postępowaniu nieprocesowym, Warszawa 2013, s. 389.

${ }^{11}$ H. Haak, Ochrona prawna udzielana przez sad opiekuńczy, Toruń 2002, s. 253.

12 Por. W. Broniewicz, A. Marciniak, I. Kunicki, Postępowanie cywilne w zarysie, Warszawa 2016, s. 282.

${ }_{13}$ Por. W. Siedlecki, Z. Świeboda, op. cit., s. 79; W. Broniewicz, A. Marciniak, I. Kunicki, op. cit., s. 407.

${ }_{14}$ Do postanowień co do istoty sprawy mają odpowiednie zastosowanie przepisy o wyrokach (art. 316-332, 350-353 i 363-366 w zw. z art. 13 § 2 k.p.c.). Por. W. Siedlecki, Z. Świeboda, op. cit., s. 80, 81; I. Kunicki, [w:] Kodeks postepowania cywilnego, t. 1, s. 1612; J. Gudowski, op. cit., s. 80-85.

${ }_{15}$ I. Kunicki, [w:] Kodeks postepowania cywilnego, t. 1, s. 1612; W. Broniewicz, A. Marciniak, I. Kunicki, op. cit., s. 407. Do postanowień proceduralnych znajdują odpowiednie zastosowanie przepisy o postanowieniach sądu w procesie - art. 354-361 k.p.c. Por. I. Kunicki, [w:] Kodeks postępowania cywilnego, t. 1, s. 1612; W. Siedlecki, Z. Świeboda, op. cit., s. 80-81. 


\section{CHARAKTER PRAWNY ORZECZENIA}

Z punktu widzenia klasyfikacji orzeczeń na zasądzające, ustalające oraz kształtujące, postanowienie sądu opiekuńczego uwzględniające wniosek o wyrażenie zgody na pobranie od małoletniego szpiku lub komórek krwiotwórczych krwi obwodowej, należy zaliczyć do orzeczeń kształtujących ${ }^{16}$. Postanowienie pozytywne sądu opiekuńczego wydane $\mathrm{w}$ analizowanym postępowaniu spełnia bowiem kryteria orzeczeń kształtujących, tj. uwzględniających wniosek o ukształtowanie stosunku prawnego lub prawa ${ }^{17}$. Postanowienie to powoduje zmianę istniejącego stanu prawnego ${ }^{18}$. Bez zgody sądu opiekuńczego nie może nastąpić pobranie od małoletniego szpiku lub komórek krwiotwórczych krwi obwodowej na rzecz jego rodzeństwa. Pobranie takie byłoby bezprawne. W konsekwencji omawiane postanowienie tworzy uprawnienie do dokonania zabiegu pobrania od małoletniego szpiku lub komórek krwi.

Natomiast postanowienie sądu opiekuńczego oddalające wniosek o wyrażenie zgody na pobranie od małoletniego szpiku lub komórek krwiotwórczych krwi obwodowej należy zaliczyć do orzeczeń ustalających. Orzeczenia oddalające mają w zasadzie charakter orzeczeń ustalających ${ }^{19}$. W przypadku wydania postanowienia oddalającego wskazany wniosek sąd dokonuje ustaleń w zakresie nieistnienia przesłanek pozytywnych niezbędnych do wyrażenia zgody na pobranie szpiku lub komórek krwi bądź istnienia przesłanek negatywnych. Postanowienie takie nie zmienia zaś istniejącego stanu prawnego.

\section{CECHY I SKUTKI ORZECZENIA}

\section{Prawomocność}

Postanowienia co do istoty sprawy wydane w postępowaniu nieprocesowym korzystają, podobnie jak wyroki w procesie, z prawomocności formalnej i materialnej. Prawomocność formalna to wynikająca z niezaskarżalności orzeczenia w drodze

16 Orzeczenie kształtujące pokrywa się pojęciowo z orzeczeniem konstytutywnym. Por. A. Góra-Błaszczykowska, [w:] Kodeks postępowania cywilnego, t. 1, s. 841; W. Broniewicz, A. Marciniak, I. Kunicki, op. cit., s. 287.

${ }^{17}$ Por. W. Broniewicz, A. Marciniak, I. Kunicki, op. cit., s. 286. W przypadku orzeczeń konstytutywnych zmiana w sferze prawnej jest dopiero następstwem (skutkiem) orzeczenia. W takim wypadku ono samo jest zdarzeniem cywilnoprawnym, wskutek czego ma charakter konstytutywny. Por. K. Korzan, Orzeczenia zastępujące oświadczenia woli w sądowym postępowaniu cywilnym, Warszawa 1977, s. 41-42; idem, Orzeczenia konstytutywne w postępowaniu cywilnym, Warszawa 1972, s. 79 i n.

${ }_{18}$ Por. W. Broniewicz, A. Marciniak, I. Kunicki, op. cit., s. 286.

19 Por. ibidem. 
środków odwoławczych i szczególnych środków zaskarżenia niemożność uchylenia albo zmiany orzeczenia ${ }^{20}$. Postanowienie wydane w postępowaniu nieprocesowym staje się prawomocne $\mathrm{z}$ chwilą, gdy nie przysługuje do niego środek odwoławczy lub inny środek zaskarżenia (art. $363 \mathrm{w}$ zw. z art. $13 \S 2$ k.p.c.). Postanowienie w przedmiocie wyrażenia zgody na pobranie od małoletniego szpiku lub komórek krwi staje się prawomocne formalnie, gdy:

a) uczestnik uprawniony do wniesienia apelacji nie wniósł jej w ustawowym terminie; postanowienie staje się wówczas prawomocne po bezskutecznym upływie terminu do wniesienia apelacji, albo

b) uczestnik wniósł apelację, jednakże:

- apelacja została odrzucona; odrzucenie środka zaskarżenia nie ma wpływu na uprawomocnienie się postanowienia sądu opiekuńczego, postanowienie to uprawomocni się z taką chwilą, jakby środek zaskarżenia nie został nigdy wniesiony ${ }^{21}$,

- apelacja została oddalona; postanowienie uprawomocni się z chwilą uprawomocnienia się orzeczenia rozstrzygającego ten środek zaskarżenia ${ }^{22}$,

- sąd umorzył postępowanie wywołane wniesieniem apelacji; postanowienie uprawomocni się z chwilą wydania postanowienia umarzającego postępowanie ${ }^{23}$.

Prawomocność materialna to moc wiążąca orzeczenia prawomocnego formal$n^{2}{ }^{24}$. Pokrywa się ona pojęciowo ze skutecznością orzeczenia.

\section{Niezmienność}

Zgodnie z art. 523 k.p.c. prawomocne postanowienie orzekające co do istoty sprawy nie może być zmienione ani uchylone, chyba że przepis szczególny stanowi inaczej. Jednakże prawomocne postanowienie oddalające wniosek sąd może zmienić w razie zmiany okoliczności sprawy. Mimo braku wyraźnego uregulowania w przepisach postępowania nieprocesowego również nieprawomocne postanowienie orzekające co do istoty sprawy nie może być zmienione ani uchylone, ponieważ stoi temu na przeszkodzie związanie sądu tym postanowieniem od chwili jego wydania (art. $332 \S 1 \mathrm{w}$ zw. z art. $13 \S 2$ k.p.c.). W konsekwencji przepis art. 523

${ }^{20}$ Por. ibidem, s. 307. Por. także: K. Korzan, Orzeczenia konstytutywne..., s. 108; A. Góra-Błaszczykowska, op. cit., s. 942.

${ }^{21}$ I. Kunicki, [w:] Kodeks postępowania cywilnego, t. 1, s. 1576. Por. także: wyrok SN z dnia 10 marca 1993 r., I CRN 19/93, OSNCP 1993, nr 11, poz. 205.

${ }^{22}$ I. Kunicki, [w:] Kodeks postępowania cywilnego, t. 1, s. 1576.

${ }^{23}$ Ibidem.

${ }^{24}$ W. Broniewicz, A. Marciniak, I. Kunicki, op. cit., s. 308; A. Góra-Błaszczykowska, op. cit., s. 942 . 
zd. 1 k.p.c jest zbędny. Wystarczające byłoby bowiem uregulowanie odstępstw od związania sądu wydanym orzeczeniem ${ }^{25}$.

Prawomocne postanowienia orzekające, co do istoty sprawy oddalające wniosek (tj. o treści negatywnej), korzystają z niezmienności pod warunkiem, że nie doszło do zmiany okoliczności sprawy. Chodzi tu wyłącznie o okoliczności zaistniałe po uprawomocnieniu się postanowienia ${ }^{26}$. Wnioskując a maiori ad minus, należy uznać, że tym bardziej może być zmienione, w razie zmiany okoliczności sprawy, postanowienie negatywne nieprawomocne.

Jak zaznaczono, prawomocne postanowienia orzekające pozytywnie co do istoty sprawy mogą być zmienione lub uchylone na podstawie przepisu szczególnego nawet wtedy, gdy nie uległy zmianie okoliczności faktyczne ${ }^{27}$. W konsekwencji $\mathrm{w}$ analizowanym postępowaniu obowiązuje zasada odmienna w stosunku do wskazanej wyżej ogólnej zasady niezmienności prawomocnych orzeczeń co do istoty sprawy. Sąd opiekuńczy może zmienić swe postanowienie nawet prawomocne, jeżeli wymaga tego dobro osoby, której dotyczy postępowanie (art. 577 k.p.c.). Zgodnie ze wskazanym przepisem sąd ma możliwość szybkiego dostosowania wydanego postanowienia do każdej sytuacji, w jakiej może znaleźć się osoba, której dotyczy postępowanie ${ }^{28}$. Sąd opiekuńczy, który wyraził zgodę na pobranie od małoletniego szpiku lub komórek krwiotwórczych krwi obwodowej, może zatem zmienić swoje prawomocne postanowienie, choćby okoliczności faktyczne sprawy nie uległy zmianie ${ }^{29}$, gdyż kieruje się on wyłącznie dobrem osoby, której postępowanie dotyczy, tj. dobrem małoletniego dawcy lub biorcy ${ }^{30}$. W świetle art. 577 k.p.c. jedynym kryterium zmiany postanowienia jest dobro dziecka. Zmiana prawomocnego postanowienia jest dopuszczalna nie tylko w przypadku zmiany okoliczności faktycznych, ale również wtedy, gdy sąd opiekuńczy swoje poprzednie postanowienie później oceni jako błędne ${ }^{31}$.

Spełnienie przesłanki dobra małoletniego upoważnia sąd opiekuńczy do zmiany lub uchylenia postanowienia z urzędu, w tym w sprawie, która może być wszczęta

${ }^{25}$ I. Kunicki, [w:] Kodeks postepowania cywilnego, t. 1, s. 1631.

${ }^{26}$ M. Rejdak, op. cit., s. 710-711.

27 W. Siedlecki, [w:] J. Policzkiewicz, W. Siedlecki, E. Wengerek, Postępowanie nieprocesowe, Warszawa 1980, s. 80.

${ }_{28}$ Por. uzasadnienie postanowienia SN z dnia 6 listopada 1972 r., III CRN 281/72, OSNCP 1973, nr 10, poz. 172.

${ }^{29}$ Por. K. Markiewicz, op. cit., 416.

${ }^{30}$ Por. W. Siedlecki, Z. Świeboda, op. cit., s. 85; M. Malczyk, [w:] Kodeks postępowania cywilnego, t. 1, s. 1683.

${ }_{31}$ H. Haak, Ochrona prawna udzielana przez sąd opiekuńczy, s. 258-259. W nauce wyrażono jednak dyskusyjne zapatrywanie, że na podstawie art. 577 k.p.c. sąd opiekuńczy nie może w wyniku odmiennej oceny tego samego stanu faktycznego zmienić swego postanowienia, jeżeli zostało ono poddane kontroli instancyjnej. Zob. K. Markiewicz, op. cit., s. 417; J. Gudowski, op. cit., s. 288-289. 
tylko na wniosek ${ }^{32}$. Wobec tego w przedmiotowym postępowaniu sąd może z urzędu zmienić lub uchylić swoje prawomocne postanowienie, mimo że postępowanie to może być wszczęte wyłącznie na wniosek.

Należy tu zauważyć, że wskazany przepis art. 577 k.p.c. pozostaje aktualny $\mathrm{w}$ zakresie postanowienia merytorycznego ( $\mathrm{tj}$. postanowienia w przedmiocie wyrażenia zgody na pobranie od małoletniego szpiku lub komórek krwi) jedynie wówczas, gdy małoletni, w stosunku do którego sąd wyraził zgodę na pobranie od niego szpiku lub komórek krwiotwórczych krwi obwodowej, nie został jeszcze poddany eksplantacji. Po dokonaniu zabiegu transplantacji zmiana prawomocnego postanowienia jest bezprzedmiotowa. Sąd opiekuńczy jest więc w omawianym postępowaniu ograniczony czasowo $\mathrm{w}$ zakresie skorzystania $\mathrm{z}$ kompetencji do zmiany prawomocnego postanowienia orzekającego co do istoty sprawy.

\section{Powaga rzeczy osądzonej}

Powaga rzeczy osądzonej polega na wiążącym ustaleniu istnienia albo nieistnienia określonej normy prawnej indywidualno-konkretnej lub jurysdykcyjnej (aspekt pozytywny), a także stanowi okoliczność niepozwalającą na ponowne rozpoznanie danej sprawy (aspekt negatywny) ${ }^{33}$.

Powaga rzeczy osądzonej to jedna $\mathrm{z}$ cech prawomocnego wyroku (art. 366 k.p.c. $)^{34}$. W postępowaniu nieprocesowym ma ona zastosowanie do postanowień co do istoty sprawy na podstawie art. $13 \S 2$ k.p.c. ${ }^{35}$ Postanowienia te uzyskują powagę rzeczy osądzonej zawsze $\mathrm{z}$ chwilą uprawomocnienia się, mimo że czasem korzystają z natychmiastowej skuteczności (art. 578 § 1 k.p.c.) ${ }^{36}$.

W konsekwencji powyższych uwag należy przyjąć, że postanowienie w przedmiocie wyrażenia zgody na pobranie od małoletniego szpiku lub komórek krwi uzyskuje powagę rzeczy osądzonej z chwilą jego uprawomocnienia się, co oznacza niedopuszczalność ponownego rozpoznania tej samej sprawy ${ }^{37}$. Ponownie złożony wniosek wszczynający postępowanie w przedmiocie wyrażenia zgody na pobranie od małoletniego szpiku lub komórek krwi podlega odrzuceniu (art. $199 \S 1$ pkt 2 W zW. z art. $13 \S 2$ k.p.c. $)^{38}$.

32 T. Żyznowski, [w:] Kodeks postępowania cywilnego, t. 2: Komentarz. Art. 367-729, red. A. Marciniak, K. Piasecki, Warszawa 2016, s. 826-827.

33 W. Broniewicz, A. Marciniak, I. Kunicki, op. cit., s. 309-310.

${ }_{34}$ Por. ibidem, s. 312. Por. także: A. Góra-Błaszczykowska, op. cit., s. 950.

35 Por. I. Kunicki, [w:] Kodeks postepowania cywilnego, t. 1, s. 1595.

${ }^{36}$ Ibidem, s. 1596.

${ }^{37}$ Ibidem, s. 1602.

${ }^{38}$ Ibidem. 


\section{Skuteczność i wykonalność}

Zgodnie z art. $521 \S 1$ k.p.c., jeżeli przepis szczególny inaczej nie stanowi, postanowienie orzekające co do istoty sprawy staje się skuteczne - a jeżeli wymaga wykonania, jest też wykonalne - po uprawomocnieniu. Jeżeli postanowienie takie ulega z mocy ustawy wykonaniu przed uprawomocnieniem się, sąd, który je wydał, może stosownie do okoliczności wstrzymać jego wykonanie (art. $521 \S 2$ k.p.c.). Skuteczność postanowień orzekających co do istoty sprawy w postępowaniu nieprocesowym polega na ich mocy wiążącej. Skuteczność ta jest w zasadzie rezultatem uprawomocnienia się postanowienia. Oznacza ona zatem prawomocność materialną, która w wypadkach wskazanych w ustawie ma charakter natychmiastowy ${ }^{39}$.

Wykonalność postanowień orzekających co do istoty sprawy nie jest - odmiennie niż występuje to $\mathrm{w}$ odniesieniu do postanowień proceduralnych - postacią ich skuteczności ${ }^{40}$. Postanowienia orzekające co do istoty sprawy w postępowaniu nieprocesowym stają się co do zasady wykonalne, jeżeli wymagają wykonania, po uprawomocnieniu się.

Natomiast postanowienia sądu opiekuńczego są skuteczne i wykonalne z chwilą ich ogłoszenia, a gdy ogłoszenia nie było - z chwilą ich wydania (art. $578 \S 1$ k.p.c.). Wskazany art. $578 \S 1$ k.p.c. jest przepisem szczególnym w stosunku do przywołanego wyżej art. 521 k.p.c. W konsekwencji postanowienie merytoryczne sądu opiekuńczego wydane w analizowanym postępowaniu jest natychmiast skuteczne z mocy ustawy (tj. wiążące). Skuteczność postanowienia sądu opiekuńczego w przedmiocie wyrażenia zgody na pobranie od małoletniego szpiku lub komórek krwiotwórczych krwi obwodowej polega na zdatności do wywołania skutków prawnych, które wynikają z treści tego postanowienia ${ }^{41}$. Skutek prawny w postaci wyrażenia zgody przez sąd opiekuńczy, która warunkuje dopuszczalność pobrania od małoletniego szpiku lub komórek krwiotwórczych krwi obwodowej, powstaje zatem z chwilą ogłoszenia postanowienia, a gdy ogłoszenia nie było - z chwilą jego wydania. $Z$ tą chwilą możliwe będzie też dokonanie zabiegu transplantacji.

Sąd nie określa czasu, w jakim dopuszczalne jest pobranie wskazanego w orzeczeniu materiału transplantacyjnego od określonego małoletniego dawcy na rzecz konkretnego biorcy. Nie oznacza to, że orzeczenie sądu opiekuńczego jest skuteczne przez całe życie potencjalnego dawcy. Przyjąć trzeba, że granicę skuteczności tego orzeczenia stanowi osiągnięcie przez potencjalnego dawcę pełnoletniości. Wówczas

39 W. Broniewicz, A. Marciniak, I. Kunicki, op. cit., s. 407. Por. także: H. Dolecki, Ingerencja sądu opiekuńczego w wykonywanie władzy rodzicielskiej, Warszawa 1983, s. 104-105. Szerzej na temat skuteczności orzeczeń: I. Kunicki, Związanie sądu wydanym orzeczeniem w procesie cywilnym, Warszawa 2010, s. 283-286.

${ }^{40}$ W. Broniewicz, A. Marciniak, I. Kunicki, op. cit., s. 407.

${ }^{41}$ Por. M. Malczyk, op. cit., s. 1684. 
nie jest już on osobą małoletnią, więc odpada przesłanka uzyskania zgody sądu opiekuńczego na pobranie od niego szpiku lub komórek krwi.

Wykonalność jest następstwem uprawomocnienia się orzeczenia pod warunkiem, że nadaje się ono do wykonania $\mathrm{w}$ drodze egzekucji sądowej ${ }^{42}$. Postanowienia sądu opiekuńczego są co do zasady natychmiast wykonalne. Jednakże postanowienie w przedmiocie wyrażenia zgody na pobranie od małoletniego szpiku lub komórek krwiotwórczych krwi obwodowej nie korzysta z cechy wykonalności, gdyż nie nadaje się ono do wykonania $\mathrm{w}$ drodze egzekucji sądowej. Trudno wyobrazić sobie egzekucję takiego postanowienia. Jeżeli przedmiotowa zgoda została przez sąd udzielona, analizowane postanowienie merytoryczne jest skuteczne $i$ istnieje możliwość dokonania zabiegu transplantacji. Nie można przy tym zmusić lekarza do wykonania wskazanego zabiegu, o ile - pomimo wyrażonej zgody - nie doszłoby do pobrania od małoletniego szpiku lub komórek krwiotwórczych krwi obwodowej z powodu np. pogorszenia się zdrowia małoletniego dawcy. Ponadto, jak wyżej wskazano, przedmiotowe postanowienie ma charakter kształtujący, a nie zasądzający. Orzeczenia takie nie zawierają stwierdzenia obowiązku spełnienia określonego świadczenia i nie nadają się do egzekucji, ponieważ egzekucja może być przeprowadzona jedynie co do świadczeń. Egzekucja jest ponadto zbędna, gdyż cel orzeczenia konstytutywnego realizuje się z chwilą jego uprawomocnienia ${ }^{43}$.

\section{UZASADNIENIE POSTANOWIENIA I DORĘCZENIE UZASADNIENIA}

Zgodnie z art. 517 k.p.c. sąd uzasadnia i doręcza postanowienie stosownie do art. 357 k.p.c., lecz nie doręcza się postanowienia uczestnikowi, który będąc obecnym na posiedzeniu, po ogłoszeniu postanowienia zrzekł się jego doręczenia. $\mathrm{W}$ zakresie doręczenia i uzasadnienia postanowienia w przedmiocie wyrażenia zgody przez sąd opiekuńczy na pobranie od małoletniego szpiku lub komórek krwiotwórczych krwi obwodowej stosuje się art. 357 k.p.c. ${ }^{44} \mathrm{~W}$ konsekwencji postanowienia ogłoszone na posiedzeniu jawnym sąd uzasadnia tylko wtedy, gdy podlegają one zaskarżeniu i tylko na żądanie uczestnika zgłoszone w terminie tygodniowym od dnia ogłoszenia postanowienia. Postanowienia te doręcza się tylko temu uczestnikowi, który zażądał sporządzenia uzasadnienia i doręczenia postanowienia z uzasadnieniem (art. $357 \S 1 \mathrm{w}$ zw. z art. 517 k.p.c.).

42 Ibidem.

43 Por. K. Korzan, Orzeczenia konstytutywne w postępowaniu cywilnym, s. 54; idem, Orzeczenia zastęujące..., s. 162.

44 Przepis art. 357 k.p.c. znajduje zastosowanie zarówno do postanowień orzekających co do istoty sprawy, jak i postanowień proceduralnych. Por. I. Kunicki, [w:] Kodeks postęowania cywilnego, t. 1, s. 1614. 
Postanowienia wydane na posiedzeniu niejawnym sąd doręcza z urzędu wszystkim uczestnikom, chyba że przepis szczególny stanowi inaczej. Gdy uczestnikowi przysługuje środek zaskarżenia, postanowienie należy doręczyć z uzasadnieniem. Ponadto, doręczając postanowienie, trzeba pouczyć uczestnika występującego w sprawie bez adwokata, radcy prawnego, rzecznika patentowego lub radcy Prokuratorii Generalnej Rzeczypospolitej Polskiej o dopuszczalności, terminie i sposobie wniesienia środka zaskarżenia (art. $357 \S 2 \mathrm{w}$ zw. z art. 517 k.p.c.). Uzasadnienie postanowienia należy sporządzić $\mathrm{w}$ ciągu tygodnia od dnia wydania postanowienia na posiedzeniu niejawnym. Jeżeli postanowienie wydano na posiedzeniu jawnym, termin tygodniowy liczy się od dnia, w którym zażądano jego doręczenia, a gdy żądania takiego nie było - od dnia wniesienia zażalenia, zaś w przypadku tzw. postanowień merytorycznych - od dnia wniesienia apelacji (art. $357 \S 3 \mathrm{w} \mathrm{zW}$. $\mathrm{z}$ art. $13 \S 3$ k.p.c.). Postanowień, które odnoszą się wyłącznie do innych osób (świadka, biegłego, osoby trzeciej), nie doręcza się uczestnikom. Osobom, których te postanowienia dotyczą, doręcza się je tylko wówczas, gdy nie były one obecne na posiedzeniu, na którym postanowienia te zostały wydane (art. $357 \S 4 \mathrm{w} \mathrm{zw}$. $\mathrm{z}$ art. $13 \S 2$ k.p.c.).

Sąd nie doręcza postanowienia uczestnikowi, który będąc obecnym na posiedzeniu, po ogłoszeniu postanowienia zrzekł się jego doręczenia (art. 517 in fine k.p.c.). Możliwość zrzeczenia się doręczenia dotyczy postanowień ogłoszonych na posiedzeniu jawnym, a nie postanowień wydanych na posiedzeniu niejawnym ${ }^{45}$. Jak zostało już wskazane, w przedmiocie wyrażenia zgody na pobranie od małoletniego szpiku lub komórek krwiotwórczych krwi obwodowej sąd opiekuńczy orzeka co do zasady na posiedzeniu jawnym niebędącym rozprawą. W konsekwencji w analizowanym postępowaniu co do zasady możliwe będzie zrzeczenie się doręczenia postanowienia w przedmiocie wyrażenia zgody na pobranie od małoletniego szpiku lub komórek krwi.

\section{BIBLIOGRAFIA}

Broniewicz W., Marciniak A., Kunicki I., Postępowanie cywilne w zarysie, Warszawa 2016.

Dolecki H., Ingerencja sqadu opiekuńczego w wykonywanie władzy rodzicielskiej, Warszawa 1983.

Góra-Błaszczykowska A., [w:] Kodeks postępowania cywilnego, t. 1: Komentarz. Art. 1-729, red. A. Góra-Błaszczykowska, Warszawa 2016.

Gudowski J., [w:] Kodeks postepowania cywilnego. Komentarz, t. 4: Postepowanie rozpoznawcze. Postępowanie zabezpieczające, red. T. Ereciński, Warszawa 2016.

Guzik-Makaruk E.M., Transplantacja organów, tkanek i komórek w ujęciu prawnym i kryminologicznym, Białystok 2008.

Haak H., Ochrona prawna udzielana przez sąd opiekuńczy, Toruń 2002.

${ }^{45}$ W. Siedlecki, Z. Świeboda, op. cit., s. 81. 
Haak H., Władza rodzicielska. Komentarz, Torun 1995.

Haberko J., [w:] J. Haberko, I. Uhrynowska-Tyszkiewicz, Ustawa o pobieraniu, przechowywaniu i przeszczepianiu komórek, tkanek i narządów. Komentarz, Warszawa 2014.

Kallaus A., Udział osoby matoletniej w postępowaniu opiekuńczym, Poznań 2015.

Korzan K., Orzeczenia konstytutywne w postępowaniu cywilnym, Warszawa 1972.

Korzan K., Orzeczenia zastępujące oświadczenia woli w sądowym postępowaniu cywilnym, Warszawa 1977.

Kunicki I., [w:] Kodeks postepowania cywilnego, t. 1: Komentarz. Art. 1-729, red. A. Góra-Błaszczykowska, Warszawa 2016.

Kunicki I., Związanie sadu wydanym orzeczeniem w procesie cywilnym, Warszawa 2010.

Malczyk M., [w:] Kodeks postępowania cywilnego, t. 1: Komentarz. Art. 1-729, red. A. Góra-Błaszczykowska, Warszawa 2016.

Markiewicz K., Zasady orzekania w postepowaniu nieprocesowym, Warszawa 2013.

Mularski K., Problematyka przeszczepu od małoletniego żywego dawcy, „Państwo i Prawo” 2013, z. 7.

Postanowienie SN z dnia 6 listopada 1972 r., III CRN 281/72, OSNCP 1973, nr 10, poz. 172.

Rejdak M., [w:] Kodeks postępowania cywilnego, t. 2: Komentarz. Art. 367-729, red. A. Marciniak, K. Piasecki, Warszawa 2016.

Siedlecki W., [w:] J. Policzkiewicz, W. Siedlecki, E. Wengerek, Postepowanie nieprocesowe, Warszawa 1980.

Siedlecki W., Zasady orzekania oraz zasady zaskarżania orzeczeń sądowych w postępowaniu cywilnym w świetle orzecznictwa Sąu Najwyższego, Warszawa 1982.

Siedlecki W., Zasady orzekania w postępowaniu cywilnym, „Nowe Prawo” 1965, nr 6.

Siedlecki W., Zasady wyrokowania w procesie cywilnym, Warszawa 1957.

Siedlecki W., Świeboda Z., Postępowanie nieprocesowe, Warszawa 2001.

Ustawa z dnia 17 listopada 1964 r. - Kodeks postępowania cywilnego (t.j. Dz.U. z 2016 r., poz. 1822).

Ustawa z dnia 1 lipca 2005 r. o pobieraniu, przechowywaniu i przeszczepianiu komórek, tkanek i narządów (t.j. Dz.U. z 2015 r., poz. 1000).

Wyrok SN z dnia 10 marca 1993 r., I CRN 19/93, OSNCP 1993, nr 11, poz. 205.

Żyznowski T., [w:] Kodeks postępowania cywilnego, t. 2: Komentarz. Art. 367-729, red. A. Marciniak, K. Piasecki, Warszawa 2016.

\section{SUMMARY}

This article concerns the ruling rendered in one of the civil proceedings which are regulated in Act of 1 July 2005 on the cell, tissue and organ recovery, storage and transplantation, i.e. in the proceeding on the subject of giving consent of the guardianship court to collect bone marrow or peripheral blood haematopoietic cells from the juvenile. First of all, the author describes the issues pertaining to the content of the ruling, its time and place, as well as its form and legal nature. Next, the author presents the characteristics and results of the ruling, including: legitimacy, inalterability, res iudicata, effectiveness and enforceability. Moreover, the author touches upon a very important issue of justification of ruling.

Keywords: ruling of the guardianship court; proceeding on the subject of consent to collect bone marrow or peripheral blood haematopoietic cells from the juvenile; consent of the guardianship court 